\title{
FACTORS ASSOCIATED WITH ANTENATAL CARE UPTAKE AND INCIDENCE OF LOW BIRTHWEIGHT IN KUPANG, EAST NUSA TENGGARA
}

\author{
Roslin E.M. Sormin'), Intje Picauly²), Ina Debora Ludji²) \\ 1) School of Health Sciences Maranatha, Kupang \\ 2) Masters Program in Public Health, Universitas Nusa Cendana
}

\begin{abstract}
Background: The importance of antenatal care (ANC) cannot be understated because it could detect abnormalities and preventable illnesses in mother and child, including low birth weight (LBW). This study aimed to determine factors associated with ANC uptake and LBW in Kupang, East Nusa Tenggara.

Subjects and Method: This was a cross-sectional study conducted at several Puskesmas (Community Health Care) in Kupang, East Nusa Tenggara, in February and March 2015. A sample of 39 pregnant mothers were selected for this study. The dependent variable were ANC uptake and incidence of LBW. The independent variables were maternal education, husband support, general health check ups. The data were colected by questionnaire and maternal and child health record. The data analyzed by a multiple logistic regression.

Results: ANC uptake decreased with lower maternal education $(\mathrm{OR}=0.12 ; 95 \%$ $\mathrm{CI}=0.02$ to $0.69 ; \mathrm{p}=0.017)$, weak husband support $(\mathrm{OR}=0.06 ; 95 \% \mathrm{CI}=0.06$ to $0.67 ; \mathrm{p}=0.022)$, and absence of general check ups $(\mathrm{OR}=0.18 ; 95 \% \mathrm{CI}=0.04$ to $0.83 ; \mathrm{p}=0.028)$. Regular ANC uptake was associated with lower risk of LBW (OR= $0.54 ; 95 \% \mathrm{CI}=0.32$ to $0.94 ; \mathrm{p}<0.001$ ).

Conclusion: Antenatal care uptake decreases with lower maternal education, weak husband support, and absence of general check ups. Regular ANC uptake is associated with lower risk of LBW.
\end{abstract}

Keywords: antenatal care, low birth weight, pregnant women.

\section{Correspondence:}

Roslin E.M. Sormin. School of Health Sciences Maranatha, Kupang, East Nusa Tenggara, Indonesia. Email: roslin.sormin78@gmail.com.

Mobile: 081339440442. 